\title{
How to Succeed with Film Production in the Regions?
}

\author{
A Study of Key Success Factors \\ in the Norwegian Regional Film Business
}

\author{
Stine Agnete Sand
}

\begin{abstract}
This article explores what two regional film production companies in Norway do to survive and succeed with their goals. The production of feature films in Norway is largely an Oslo-based effort, but despite this reality, there are companies in the regions that produce feature films. The analysis draws on semi-structured interviews with eight employees in two companies. Mer Film has in relatively short time managed to attract talented directors and establish networks with international, critically acclaimed production companies. Filmbin was one of the first film companies in Norway who committed themselves to the production of films for children. The article shows that success must be related to context and that reputation, talent development and choice of genre, geographical location, networking and social capital, risk diversification, entrepreneurship, organizational culture and leadership, are essential factors for the companies.
\end{abstract}

Keywords: regional film, success, film companies, knowledge-based resources

\section{Introduction}

According to a report on the economy and financial flows in the Norwegian film business (Ryssevik et al. 2014), Norwegian film production is centralized and characterized by small companies, low profitability and movies that often end up running deficits. Low production volume represents ongoing challenges for the film business, and particularly for regional filmmakers. The production of feature films, after all, is largely an Oslobased effort, and in 2015, 80 per cent of the funding from the Norwegian Film Institute (NFI) went to the capital area (NFI 2015). The article discusses how two regional companies survive in a difficult business.

This is a highly relevant issue because filmmaking is important to the Norwegian authorities, who have described film as one of the most important cultural expressions of the era (St.meld. 30 (2014-2015)). It is a stated goal that Norwegian films should succeed both in Norway and internationally, and that the films should be of good qual- 
ity. The national film policy also states that the film companies need to be more economically viable. Film production should be less dependent upon public funding, and also contribute to economic growth. The importance of culture as a source of national economic growth is a talking point of both politicians and people within the cultural sector (Bille 2013: 165). The government's second objective is to strengthen regional film production, in the interests of providing a real counterweight to the dominance of the capital (St.meld. 30 (2014-2015): 12).

Little research has looked at the actual relationships between small companies, their strategies and performance (Gibcus \& Kemp 2003: 41). In this context, I discuss what two well-established regional companies do to survive and succeed with their goals. I explore key success factors, with a focus on knowledge-based resources, and how the use of this competence can be advantageous (Barney 1991, Wernerfelt 1984). The article is based on interviews with eight employees in the two regional film production companies Mer Film, which has an office in Bergen, Western Norway and in Tromsø, Northern Norway, and Filmbin, which has an office in Lillehammer, Eastern Norway.

\section{What does it mean to be successful?}

Screenwriter William Goldman's remark "Nobody knows anything” is often quoted as an illustration of the uncertainty in the film business - it is difficult to predict a success, and the rate of financial failures is high (Simonton 2009). According to Simonton, there are three main criteria by which a film's success can be evaluated: critical evaluations, financial performance, and movie awards. These criteria represent both aesthetic and economic assessments. Several studies focus on commercial success, including blockbusters and how to predict financial success (Collins et al. 2002, Litman \& Kohl 1989). Research on critical evaluations and movie awards often relate this to financial performance as well (Ginsburgh 2003).

This article has a different starting point. Discussing the regional film business in a small country like Norway, the concept of success must be related to its context. Profitability in the private film and television business in Norway is poor (Ryssevik et al. 2014). The government's increased focus on sustainability and economic viability is related to this. The Norwegian film business is fragmented, comprised mostly of small companies with low earnings. This applies to Scandinavia as a whole as well - there are few large, robust firms, and many companies produce less than a film per year on average (Bondebjerg \& Redvall 2011: 9).

Secondly, as in many other countries in Europe, the government in Norway provides substantial subsidies to filmmakers in order to maintain a domestic industry. This means that the films do not have to be as profitable for the industry to survive. The companies in Norway do not solely depend on private money when financing a film and this makes their situation quite different from, for instance, the industry in Los Angeles.

Thirdly, much of the economic research that deals with companies assumes that the aim is to achieve economic growth and profitability. What distinguishes Norwegian regional film companies in this regard is that profit is not necessarily the main goal. Any company depends upon a certain amount of income, but one characteristic of people working with film (and others in creative professions) is that their creative goals, and the inner motivation they possess to achieve them, can be more important than high 
salaries or returns (Deuze 2011, Hesmondhalgh \& Baker 2011). Caves (2003: 74) calls this position "art for art's sake". However, as several researchers have pointed out, there is also a danger of self-exploitation (Banks 2007, Stahl 2009). For instance, many film workers accept low wages or working for free just to be able to work with film.

In this article, the concept of success is therefore based upon an understanding of 1), survival, since surviving as a company for more than five years is an achievement under the existing circumstances, and 2), art for art's sake, which means relating success to the companies' own goals. They are driven by artistic ambitions, not profitability. This commitment is possible due to public funding and various support schemes for the production of artistic films. In addition, to discuss success must also be related to the companies' commitment to their region, and their emphasis on promoting the local film business and to use the region as a starting point for their work.

\section{A resource-based perspective on companies}

The role of human capital and knowledge-based resources are gaining increased attention when discussing creative industries (Boccardelli et al. 2008). Edith Penrose (1959) describes companies' growth as a process and explores the links between company resources, management's control of these resources, and company opportunities for value creation. Strategically relevant resources for a company are, according to Barney, "those attributes of a firm's physical, human, and organizational capital that do enable a firm to conceive of and implement strategies that improve its efficiency and effectiveness" (1991: 102). Such a resource must be (1) valuable, to the extent that the resource utilises opportunities and reduces threats in the corporate environment. The broader environment of the company creates the opportunities and threats that a business strategy has to deal with (Fombrun \& Graham Astley 1983). (2) rare with regard to the company's current and potential competitors, (3) non-inimitable, and (4) non-substitutable with another resource. In addition, Barney emphasises that in order to be successful, the company needs to utilise their resources in a way that benefits the company.

Knowledge-based resources refer to "a firm's intangible know-how and skills, which cannot be imitated because they are protected by knowledge barriers" (Chan-Olmsted 2008: 166). These resources, or human skills, are important in a business context that is characterized by change and uncertainty (Miller \& Shamsie 1996: 523). Many organisational decisions are the product of a dynamic relationship between the company, its environment, and its attempt to develop and implement activities that adapt its resources to the changing environment (Chan-Olmsted 2008: 161).

Although resource-based theory is dominant in strategy research, challenges remain as to how resources should be identified, categorised and analysed (Chan-Olmsted 2008, Foss 1998: 135). This article investigates success factors and resources based on the premises that the companies are committed to pursue artistic goals, and try to survive in a difficult business. To identify and analyse success factors, I focus on three categories: human capital, or company specific competence within the company. These include experience, reputation and the ability to attract talented people. The second dimension is social, or relational capital, which includes social network and ties external to the company, for instance the capability to activate relations with film workers in the community. Thirdly, geographical location is an important factor because the companies 
are committed to the local film business and because the location gives the companies some place specific advantages.

\section{Methodological approach}

The article is based on semi-structured interviews with employees in two regional production companies, which produce fiction films. Mer Film AS has an office in Bergen and in Tromsø, and consists of three companies: Mer Film AS in Tromsø, Mer Film i Vest AS in Bergen, and Mer Filmdistribusjon AS. Owner and producer Maria Ekerhovd founded the company in 2011. She had previously produced the short film Sniffer, which was the first Norwegian film to win the Palme d'Or in Cannes (in 2006). She has also produced I am yours, Norway's Oscar candidate in 2014, and Out of nature, which won the award for best European film at the Berlin Film Festival in 2015. In 2016, the company had seven employees. ${ }^{1}$ Producer Ragna Midgard takes care of projects in the Tromsø region, while Ekerhovd develops projects in the Bergen region. Øistein Refseth is responsible for the distribution company Mer Filmdistribusjon, and Siv Dyb Wangsmo works with finance and administration. Axel Helgeland is an executive producer, advising and mentoring Ekerhovd. Helgeland has produced a number of feature films. Mer Film is an interesting case because of their results. In just five years, the company has succeeded with producing six feature films, three short films, and five co-productions with acclaimed directors such as Wim Wenders and Amat Escalante. Their films have received good reviews, and have been screened at prestigious film festivals such as Toronto and Berlin.

The second company is Filmbin, which is based in Lillehammer, central eastern part of Norway. Filmbin is interesting because it was the first production company in the Lillehammer area, a small film region compared to Oslo. Still, the company has survived for 12 years. Producer Trine Aadalen Lo, her husband, director Christian Lo, and film editor and scriptwriter Arild Tryggestad established Filmbin in Lillehammer in 2004. In 2009, they hired Nicholas Sando as a producer, and the four now co-own the company. Filmbin produces films for children and youth, and its first feature film, Rafiki, came out in 2009. It received the Norwegian cinema managers' highest award, for best children's film in 2009, and it was screened at the Berlin Film Festival the following year. The feature film The tough guys came out in 2013. It won the Audience Award at the Children's Film Festival in Kristiansand, Norway, and was screened at the Chicago International Children's Film Festival. In addition, the company has produced several short films. Filmbin also makes practical and organisational arrangements for other companies that do productions in the Lillehammer area, and it presents film courses and helps with the hiring of professionals. The company is now developing its third film.

The companies present interesting cases with regard to artistic versus commercial success. Both Mer Film and Filmbin have won awards for their films, but neither company has been particularly commercially viable. Nor is that their main objective - the desire to make quality films is greater than the desire to make lots of money. As Hesmondhalgh and Baker (2011) note, the notion of 'good work' is a minefield, but both companies have a common perception of success in the sense that they value creativity and autonomy, and that the creative ambitions are more important than the search for profit.

I conducted semi-structured interviews at the offices of Mer Film in Bergen and Filmbin in Lillehammer during June and August 2014. The interviews were structured 
around themes, and the durations were one to two hours each. In the analysing process, I read the interviews separately, and categorized the findings in each interview. Next, I compared the findings within each company before I compared the two companies. In the interpretation process, the starting point for the analysis was the research question: How do the companies, whose goals are creative and artistically motivated, go about to survive and succeed with their goals? The analyzing process does not exist within a vacuum: it is necessary to relate the research question to the situation in the Norwegian film business. This context has implications for the discussion of success factors.

Film companies rely on their good reputations when it comes to recruiting people and to securing project financing. Several researchers, as a result, have observed that it is difficult to acquire 'true' information (Caldwell 2008, Lotz 2009). The interviewees are professionals, or what Bruun calls 'exclusive' informants (2014). It is important to remember that these companies have different goals, management expectations and tolerance for risk, meaning that they might react differently to the same set of conditions. The researcher must therefore be careful not to generalise about the industry based on the situations of only a few companies (Picard 2002: 11).

The article is primarily based on interviews, but media articles about the companies are included in this study's empirical material as an additional source.

\section{An analysis of key success factors}

Some researchers argue that small companies work hard to survive from day to day and therefore do not have time for strategic planning (Hanlon \& Scott 1993). The two companies discussed here do not fall into this category, since both have invested effort into their long-term planning. In this section, I discuss factors that contribute to the companies' success.

\section{Reputation, talent development and choice of genre}

Work in the film industry is organized around projects and informal personal networks, and is often referred to as a network organization (Hirsch 1972, Jones 1996). Several studies show that reputation, successful performances, track record, and strength of ties are important to succeed (DeFillippi \& Arthur 1998, Jones \& DeFillippi 1996). Ekerhovd gained recognition when she produced the Palme d'Or winner Sniffer (directed by Bobbie Peers), Best Short Film in Cannes 2006. Her reputation as a skilled producer appears to be an important reason for Mer Film's success and resulted in the co-production of the film Everything will be fine (2015), directed by the internationally acclaimed German director Wim Wenders. Ekerhovd had collaborated with scriptwriter Bjorn Olaf Johannessen on the movie Dirk Ohm, and they simply extended their work together when Wenders's production company, Neue Road Movies, developed Johannessen's new script.

The mission of Mer Film is "to develop and produce Norwegian and international art-house films by directors with a personal artistic vision". ${ }^{2}$ The company wants to reach audiences both in Norway and internationally, producing one film per year, preferably made in Western and Northern Norway. Ekerhovd has achieved industry recognition for her commitment to art house films, which gives the company a competitive advantage 
in an industry where people privilege one's track record. This is something the company exploits in terms of securing further funding and also recruiting new talent. For example, Ekerhovd produced Bobbie Peers' short film Sniffer, and later she produced his first feature film, Dirk Ohm: The disappearing illusionist (2015). The collaborations often start with the production of a short film, to see if director and company work well together.

Like Mer Film, Filmbin focuses on artistic ambitious projects, and they want to make 'films with meaning'. Producer Trine Aadalen Lo argues that to make an impact on children and youth is one way of defining success:

After producing the film The tough guys, we received letters from schools and kids, who thanked us for making a film that puts bullying on the agenda. That made me feel that we had succeeded.

For Filmbin, the choice of genre distinguished it from most other companies when it established itself in Lillehammer in 2004. At that time, few other companies in Norway specialised in films for children and young people. Films for children were a priority in the governmental film policy statement known as "Veiviseren" [Pathfinder] which came in 2007, but few such films followed its release. NFI director Nina Refseth stated in 2012 to the film magazine Rushprint that the institute typically received few applications for the production of films for children. ${ }^{3}$ Thus Filmbin's timing was good; in addition, the company's first film received favorable reviews in the media and at festivals, which was important to establishing Filmbin's reputation. Barney (1991) calls this a "first-move advantage". Filmbin received so-called package-funded development from NFI two years after its first film premiered, which meant that it received support to develop three feature films. Still, competition in this area has increased since their initial capitalization, and Filmbin no longer stands out as it did before.

The companies' choices of genre can be seen as a strategy aimed at financial sustainability - Mer Film produces art house films, while Filmbin makes films for children and youth, and both specialties have good support structures. NFI has funds for the development and production of artistic films and a film with unique artistic potential can receive grants for up to 85 per cent of its development, production and promotion costs. Children's movies can receive up to NOK nine million in 'etterhåndsstøtte' [ex post support], while other films can receive a maximum of seven million. All Norwegian feature films that sell more than 35.000 tickets at the cinema are eligible for ex post support. This type of support is designed to compensate for the fact that Norway is a small market, and that Norwegian films have a limited chance of success on the international market. Support is equal to 100 per cent of the producer's net income, or 200 per cent for films for children. ${ }^{4}$ Mer Film's first project, I am yours (2013), and its later project Out of nature (2015) were both produced through NFI's fund called Nye veier [New roads]. To retrieve and take advantage of existing funding opportunities is a necessity in this business, and both Mer Film and Filmbin have succeeded here.

Both companies also keep few employees as permanent staff and hire more people during project periods, a normal practice in the movie business that keeps costs low (DeFillippi \& Arthur 2002). The disadvantage of this, of course, is that the knowledge and resources that accompany a typical project team are not available between projects. 


\section{Geographical location as a financial and creative resource}

In addition to reputation, track record and choice of genre, both companies have some advantages based on their geographical location. Mer Film interviewees noted that it is part of their strategy to use the Bergen and Tromsø region as a starting point for choosing collaborators and the kind of stories they want to tell. This local, not-Oslo focus is also a means of distinguishing the company. The employees at Filmbin always introduce the company as Filmbin from Lillehammer. While place is evidently an important part of the branding process, it also represents a financial and creative resource. As regional film companies, Mer Film and Filmbin have access to sources of financial support that are unavailable to companies in Oslo, including regional film funds and film centers, but also private funding that is locally inclined. Knowledge of application procedures and guidelines for funding is important to these companies. Film projects rely on public funding, and both Mer Film and Filmbin survive largely with revenues gained during a given production period.

Place also provides some creative advantages. Both companies enjoy superior access to regional talents, compelling scenery and region-based stories, and both staffs expressed the sense of feeling relatively unfettered by whatever might be happening in Oslo. In an industry that prizes innovation and originality, this free thinking can be very helpful. They take advantage of local talents, locations and stories, but also think global when it comes to networking, co-production, and distribution.

Lastly, regional film companies can contribute to place promotion, which in turn promotes them as well - an example of this is the television series Lilyhammer (Kongsrud 2013), which brought attention to Lillehammer itself, and therefore, to an extent, to Filmbin.

\section{Networking and social capital}

Mer Film's networking happens regionally, in that they consistently link up with local talents, but it also has a strong international aspect. Examples include the aforementioned co-productions with film director Wim Wenders, and the fact that Mexican NDM, the distribution company of acclaimed filmmaker Carlos Reygadas, distributed the Mer Film movie Out of Nature internationally. Networking, both regionally and internationally, allow the company to reach a wider audience, improve earnings and build its brand. Art house drama is the genre that achieves the widest circulation in Europe, as well, which is advantageous to Mer Film (Bondebjerg \& Redvall 2011: 11).

Strategic networks can provide a company with access to information, resources, markets and technologies (Zaheer et al. 2000). Ekerhovd stated in the film magazine Cinema that Wenders opened doors for Mer Film (Johnsen 2013). Other productive collaborations have involved scriptwriters who connected Mer Film to other companies; Mer Film's participation in international film festivals and active pursuit of international film company collaborators; and Ekerhovd's participation in 'Producers on the move' at Cannes in 2011, a talent program that promotes producers and helps them to establish contacts and networks. Olsberg (2012) describes international cooperation as a key factor of success in film, because the film industry is a global industry and the domestic market is not often large enough to recoup the costs of making a film. As a result, international co-productions have increased in Norway in recent years (Ryssevik 2014: 30). 
When Filmbin was established in Lillehammer in 2004, the film business was virtually nonexistent there, and politicians and local businesspeople were supportive. The filmmakers rented an office at an affordable price, and they received useful business consulting services. As the business grew up around Filmbin, it remained mutually supportive and regionally focused: "We look at each other as colleagues, not competitors", says Christian Lo of the film community in Lillehammer (interview). Filmbanken, which opened in 2012, is a building in Lillehammer that now houses eleven companies related to the film- and television business, including a regional film center and regional film fund. Filmbanken acts as a meeting place and Filmbin's Aadalen Lo underlines a commitment to stay local whenever possible (interview). For example, Filmbin hired Filmmakeriet, a company based in Filmbanken, to create a 'behind the movie' documentary when it shot the film The tough guys. Shared objectives, reciprocity and trust are aspects of social capital, and especially of those networks where participants have the same goals, have something to give one another, and expect to use one another (Fukuyama 1995, Runyan et al. 2006: 461).

Social capital has provided competitive advantages for Filmbin, and they contribute to the development of social capital by exchange of services and information. When Filmbin produced its first feature film, Rafiki, in 2009, only 20 per cent of those involved, were from the region. Four years later, when they produced The tough guys, 80 per cent of the film workers were from the area. Producer Aadalen Lo further notes that it is profitable to use local film workers, as they save NOK 50,000 per person in the budget. To hire non-local film workers represents more travel expenses and hotel costs. In addition, Filmbin enhanced the competence of local film workers by having the courage to give them new tasks. In the big picture, company staff members think this competence will strengthen the region as a film centre, which will also be beneficial to Filmbin. On a short-term basis, the company received a financial windfall, and a longterm benefit is that it now has more local film workers with experience from feature film production. Filmbin's commitment to the local film business could be described as innovative; it involves trust, risk taking, and using human resources in new ways (Wiklund 2006).

\section{Risk diversification}

According to Olsberg, the ability to take a share of revenues generated by successful content is the single most important factor in determining a company's potential for sustainability and growth (Olsberg 2012: 10). To this point, none of Mer Film or Filmbin's movies have generated profits that can be invested in new projects, meaning that the companies must continue to secure funding from external sources. According to Bondebjerg and Redvall, the film industry will need to be proactive and develop new strategies, rather than falling back on what they call traditional, defensive strategies (2011: 11). The traditional market window system that has a film shown first in theaters, then via DVD, pay TV and free TV, is changing, because new digital viewing platforms have disrupted DVD sales in particular and led to loss of revenue for distribution companies. As a result, the distribution companies are less willing to take chances. It is now more difficult for the production companies to get the distribution companies interested in distributing their films. In Filmbin's case, it decided to postpone the film project From 
mice to men in 2014. They were supposed to shoot over the summer but put the project on hold when the distributor pulled out.

Filmbin has chosen not to base their income solely on feature film production. Contract work gives them a steady supply of capital and is lower in risk than the development and production of films (Olsberg 2012: 11). Because of Filmbin's risk diversification strategy, they can lean financially on other assignments.

\section{Entrepreneurship}

Although the companies are artistically motivated, they need to survive financially. ChanOlmsted (2008: 170-171) describes strategic entrepreneurship as the way in which companies use their resources to seize opportunities that give them competitive advantages. Although all staff members at Mer Film discuss strategies, Ekerhovd has the last word. An entrepreneurial strategy, after all, derives from "the central actor's concept of his or her organization's place in its world. This is coupled with an ability to impose that vision on the organization through his or her personal control of its actions" (Mintzberg \& Waters 1985: 260). At Mer Film, for example, Ekerhovd has hired a financial manager, which allows her to concentrate on the creative work and thereby increases the efficiency of the company. This might not sound very innovative, but many production companies are run by people without specific economic or financial expertise (Olsberg 2012: 12). Mer Film also established three companies instead of one. With one company in Bergen and one in Tromsø, Mer Film can apply for funding from regional institutions in both areas. Mer Film is also no longer dependent on other distributors, because it started its own distribution company, Mer Filmdistribusjon, in 2015. This decision was based on both artistic and financial needs. By distributing its own films, Mer Film is able to represent a project that it has cultivated from the idea stage. An external distributor, on the other hand, usually arrives later in the process and has many films to handle.

The idea came from Mer Film's experience with the film Out of nature, which included a project position funded by Introfondet in Troms $\varnothing$ and Innovation Norway. Mer Film decided to see whether it could make more money on a film if it distributed the film itself. According to statistics from Film og Kino, the film sold over twenty thousand tickets, which the company saw as satisfying compared to their calculations.

Although Mer Film is not the first company to both produce and distribute films, it is a proactive and innovative arrangement that involves risk taking, and it reflects the adaptability and flexibility of the company. It took advantage of subsidies that provided funding for a pilot project to test whether distribution was something it would pursue, which made starting up the actual distribution company a less risky proposition. According to De Paoli and Hansen (2010), business support for cultural entrepreneurs has not functioned well in Norway, because the cultural sector responds differently from other sectors. According to Bille (2013: 169), one might well wonder "whether it is right to stimulate the cultural sector actively for the purpose of business development, as the industries have low earnings, and only a few are able to make money". Other researchers have pointed out that small companies are often quick to see and exploit new market opportunities, but they are often hard pressed to sustain this advantage over time (Chan-Olmsted 2008, Dean et al. 1998). Whether Mer Film will succeed with the distribution company over a long term remains to be seen. 


\section{Organizational culture and leadership}

According to Olsberg, it is important for film companies to have a strong and dynamic leader who has a vision of how the company should be developed (2012: 12). Mer Film's Maria Ekerhovd is a clear leader figure who dictates its vision. Ekerhovd has managed to cultivate trust within the company staff, which shares her interest in creating artistically ambitious movies - what they describe as her competence makes them want to work for her and Mer Film. When asked why Mer Film has thrived, finance and administrative officer Siv Dyb Wangsmo says:

Maria is the main reason. She has a strong inner compass, or intuition, on what works, plus she is very hardworking. And she takes every bit of this company very seriously, and follows up the people who are involved. Because she gives so much she also expects a lot from people around her. It is easy to be engaged by her (interview.)

According to Schein (2010: 219), the founder of a company has the greatest impact on its organisational culture, and her employees do indicate that Ekerhovd is good at delegating, and that they learn a lot from her. Each person on staff represents Mer Film at festivals, which is a way to demonstrate the company's strength and foster a sense of ownership and attachment to the company.

Filmbin, interestingly, does not have a leader. Three of the four employees started the company, and all four are currently co-owners. The staff has cultivated an egalitarian mindset, with a flat organisational structure that allows each of them a voice. According to Tryggestad, this has both advantages and disadvantages: "Sometimes it is a bit inefficient, because everyone can express their meaning about everything, but it's very useful also that everyone can speculate about everything" (interview). This degree of autonomy and validation can motivate good creative work. Olsberg (2012: 12), however, observes that many film companies are owned and driven by creative individuals "whose principal talents and experience lie in the business of bringing individual film projects to fruition. It is not always the case that these same individuals will have the knowledge and experience to push forward the company`s growth because these are essentially different things". As long as the staff is in agreement, a flat structure works. When there are differences, on the other hand, processes can take more time, because no single person has the authority to make a final decision.

The employees of both companies are relatively self-motivated and know what to do. Few employees mean that every person is important, and because the work can change quickly, these companies rely on flexibility as well. Mer Film's Siv Dyb Wangsmo, for example, usually works in finance and administration, but occasionally in other areas: "Sometimes there is much more use for someone who can obtain fake snow, than there is for someone who can sit with the budget" (interview). She experiences this as a positive aspect of her position, and it shows that she shares the values of the company and has an understanding of how people work in the film business. This flexibility also enables Ekerhovd to include the finance person in the creative work of filmmaking. There is a culture of sharing and an emphasis on fast communication. Some researchers have pointed out that there is a lack of training in small business because these companies are not concerned with growth, or are simply too busy trying to survive (Fuller-Love 2006). I have found instead that the companies have a "learning by doing" approach, and the organisational culture consists of shared and largely unspoken understandings. If these 
understandings emerge from the company's strategies and dovetail with the professional environment, the company will be more likely to succeed (Küng 2008: 173).

\section{Conclusion}

This article asks what two regional film companies in Norway, who both produce artistically ambitious films, do to succeed and survive. Obviously, there is a huge difference between the small and fragile film business in Norway, not to mention the almost nonexistent regional film business, and major film hubs in for instance Mumbai, London, or Los Angeles. Therefore, I have argued that the understanding of the ambiguous concept "success" must be discussed in relation to context. In this article, success is related to 1) the situation in the film industry, which in Norway is recognized by low earnings and low production volume, 2) art as capital, which means that, for these companies, the realization of artistically ambitious projects is more important than profitability and 3) access to public funding, which makes it possible to pursue these projects.

In addition, media products are not standardized, but instead based on creative processes and industry knowledge (Chan-Olmsted 2008: 174). This means that small companies like Filmbin and Mer Film, which do not have much capital, are still able to succeed if they exploit the unique creative resources they possess. Based on the aforementioned context, I argue that the two companies have succeeded because they have survived for more than five years, which is an achievement considered the situation in the Norwegian film business. The article shows that human and social capital are important factors. In addition, geographical location is a factor that gives both companies a competitive advantage. They are well aware of, and take advantage of, local stories, talents, scenery, not to mention locally inclined support schemes. However, Mer Films' results are exceptional in a Norwegian context - in five years, they have produced six feature films and co-produced five feature films. The company is innovative, as the start-up of the distribution company shows. Filmbin is less proactive and willing to take risks, and therefore chooses risk diversification. Mer Film also attracts talents because of their reputation, international network and they have a strong leader that can take quick decisions, while Filmbin has a flat structure and is more locally oriented. As DeFillippi and Arthur (1998: 135) argue, human capital (skills) and social capital (work relationships) form a self-reinforcing cycle of career that can either strengthen a person's career or reverse it, depending on performance. Mer Film's results confirm this, and they have produced far more films than Filmbin in a shorter period.

Both companies pursue art, but they also want to secure sustainability, which means finding ways to survive economically. Art and capital are often discussed as contrasts (Gran \& De Paoli 2005). What is essential is that their creative ambitions come first; secondly, they adjust the financial strategies based upon this goal, and not vice versa. Discussing success in relation to the small and public funding addicted Norwegian film business also poses the question if it makes sense to relate success to profitability. As several studies and the latest national film policy shows, the emphasis on film as an economic product increases. However, how the companies themselves define success and see their work does not necessarily coincide with policy goals. Due to the context in the Norwegian film business, it makes more sense to relate success to sustainability and survival, than to profitability. 


\section{Notes}

1. Aida LiPera and Elisa Fernanda Pirir started working for Mer Film after the interviews were conducted.

2. See http://www.merfilm.no/about-merfilm/. Accessed 28.10.15.

3. See http://rushprint.no/2012/05/for-fa-barnefilmsoknader/. Accessed 03.11.15.

4. See http://www.nfi.no/bransje/vare-tilskuddsordninger/kinofilm/etterhandstilskudd. Accessed 09.02.16

\section{References}

Banks, Mark (2007). The politics of cultural work. Basingstoke: Palgrave.

Barney, Jay (1991). Firm resources and sustained competitive advantage. Journal of management, 17(1): 99-120.

Bille, Trine (2013). How to develop a region through culture and creativity. The foundation Cultiva in Kristiansand, pp. 161-179 in Lindeborg, Lisbeth \& Lindkvist, Lars (eds.) The Value of Arts and Culture for Regional Development. A Scandinavian Perspective. Routledge.

Boccardelli, Paolo, Brunetta, Federica, \& Vicentini, Francesca (2008). What is critical to success in the movie industry? A study on key success factors in the Italian motion picture industry. Working Paper No 46. Dynamics of Institutions and Markets in Europe. Retrieved from www.dime-eu. org/wp14

Bondebjerg, Ib, \& Redvall, Eva Nyrup (2011). A Small Region in a Global World. Patterns in Scandinavian Film and TV Culture. Copenhagen: European Think Tank on Film and Film Policy.

Bruun, Hanne (2014). Eksklusive Informanter. Om interviewet som redskab i produktionsanalysen. Nordicom-Information, 36(1): 29-43.

Caldwell, John Thornton (2008). Production culture: industrial reflexivity and critical practice in film and television. Durham: Duke University Press.

Caves, Richard E. (2003). Contracts between art and commerce. The Journal of Economic Perspectives, 17(2): 73-83.

Chan-Olmsted, Sylvia M. (2008). Issues in strategic management, pp. 161-181 in Handbook of media management and economics New Jersey: Lawrence Erlbaum Associates.

Collins, Alan; Hand, Chris, \& Snell, Martin C. (2002). What makes a blockbuster? Economic analysis of film success in the United Kingdom. Managerial and Decision Economics, 23(6): 343-354.

Dean, Thomas J., Brown, Robert L., \& Bamford, Charles E. (1998). Differences in large and small firm responses to environmental context: Strategic implications from a comparative analysis of business formations. Strategic management journal, 19(8): 709-728.

DeFillippi, Robert J., \& Arthur, Michael B. (1998). Paradox in project-based enterprise: The case of film making. California management review, 40(2): 125-139.

DeFillippi, Robert J., \& Arthur, Michael B. (2002). 15 Paradox in Project-based Enterprise: The Case of Film Making. Managing Innovation and Change, 189.

Deuze, Mark (2011). Managing media work. London: SAGE.

Fombrun, Charles, \& Astley, Graham W. (1983). Beyond corporate strategy. Journal of Business Strategy, 3(4): 47-54.

Foss, Nicolai J. (1998). The resource-based perspective: an assessment and diagnosis of problems. Scandinavian Journal of management, 14(3): 133-149.

Fukuyama, Francis (1995). Trust: The social virtues and the creation of democracy. New York: The Free Press Paperbacks.

Fuller-Love, Nerys (2006). Management development in small firms. International Journal of Management Reviews, 8(3): 175-190.

Gibcus, P., \& Kemp, R. G. M. (2003). Strategy and small firm performance: SCALES SCientific AnaLysis of Entrepreneurship and SMEs.

Ginsburgh, Victor (2003). Awards, success and aesthetic quality in the arts. The Journal of Economic Perspectives, 17(2): 99-111.

Gran, AnneBritt., \& Paoli, Donatella de (2005). Kunst og kapital: nye forbindelser mellom kunst, estetikk og naringsliv [Art and capital: new connections between art, esthetique and business]. Oslo: Pax Forlag.

Hanlon, D., \& Scott, M. G. (1993). Strategy formation in the entrepreneurial small firm. Scottish Enterprise Foundation.

Hesmondhalgh, David, \& Baker, Sarah (2011). Creative labour: media work in three cultural industries. London: Routledge.

Hirsch, Paul M. (1972). Processing fads and fashions: An organization-set analysis of cultural industry systems. American journal of sociology, 77(4): 639-659.

Johnsen, F. (2013). Kjerringa mot strømmen [The old woman against the stream]. Cinema. 
Jones, C. (1996). Careers in project networks: The case of the film industry, pp. 58-75 in Arthur, Michael B. \& Rousseau, Denise M. The boundaryless career: A new employment principle for a new organizational era.

Jones, C., \& DeFillippi, Robert J. (1996). Back to the future in film: Combining industry and self-knowledge to meet the career challenges of the $21^{\text {st }}$ century. The Academy of Management Executive, 10(4): 89-103.

Kongsrud, T. (2013). Regional film-og tv-produksjon som katalysator for reiseliv og omdømme. (Master thesis), Lillehammer University College, Lillehammer.

Litman, B. R., \& Kohl, L. S. (1989). Predicting financial success of motion pictures: The'80s experience. Journal of Media Economics, 2(2): 35-50.

Lotz, A. D. (2009). Industry-Level Studies and the Contributions of Gitlin's Inside Prime Time. In Mayer, Vicki; Banks, Miranda J. \& John Thornton Caldwell (eds.) Production Studies. Cultural Studies of Media Industries. New York: Routledge.

NFI. (2015). Annual report. Oslo: The Norwegian Film Institute.

Olsberg, J. (2012). Building sustainable film businesses: the challenges for industry and government. London: Olsberg SPI.

de Paoli, Donnatella, \& Hansen, T. (2010). Competence About Public Measures Directed Towards the Cultural Industries - an evaluation of the Norwegian Art Council and State Innovation Bureau. Oslo.

Penrose, Edith (1959). The Theory of the Growth of the Firm. Oxford: Blackwell.

Picard, Robert G. (2002). The economics and financing of media companies: Fordham Univ Press.

Runyan, R. C., Huddleston, P., \& Swinney, J. (2006). Entrepreneurial orientation and social capital as small firm strategies: A study of gender differences from a resource-based view. The International Entrepreneurship and Management Journal, 2(4): 455-477.

Ryssevik, Jostein; Dahle, Malin, Høgestøl, Asle, \& Myhrvold-Hanssen, Thomas (2014). Åpen framtid - en utredning om økonomien og pengestrømmene i filmbransjen. Bergen: Ideas2evidence.

Schein, Edgar H. (2010). Organizational culture and leadership. San Francisco: Jossey-Bass.

Simonton, Dean Keith (2009). Cinematic success criteria and their predictors: The art and business of the film industry. Psychology \& marketing, 26(5): 400-420.

St.meld. 30 (2014-2015). En framtidsrettet filmpolitikk [A provident film policy]. Oslo: Det kongelige kulturdepartementet Retrieved from https://www.regjeringen.no/no/dokumenter/meld.-st.-30-20142015/ id $2413867 / \mathrm{sec} 1$.

Stahl, Matt (2009). Privilege and Distinction in Production Worlds: Copyright, Collective Bargaining, and Working Conditions in Media Making. In Mayer, Vicki; Banks, Miranda J., \& John T. Caldwell, (ed.) Production Studies. Cultural Studies of Media industries. New York: Routledge.

Wernerfelt, Birger (1984). A resource-based view of the firm. Strategic management journal, 5(2): 171-180.

Wiklund, Johan (2006). The sustainability of the entrepreneurial orientation - performance relationship. Entrepreneurship and the growth of firms, 141-155.

Zaheer, Akbar; Gulati, Ranjay, \& Nohria, Nitin (2000). Strategic networks. Strategic management journal, 21(3): 203. 